\title{
TRACES OF EARTHQUAKES IN THE CAVES: SAKARLAK PONOR AND KEPEZ CAVE, MERSIN, (SOUTHERN TURKEY)
}

\author{
Murat AkgöZ1 And Muhsin Eren²
}

\begin{abstract}
The study area is located in the central part of the Taurus Mountains, where karstification is widespread and strongly influenced by tectonic rise of the region and sealevel changes in the Mediterranean Sea during the Pleistocene. Young karstification in the area was largely affected by NE-SW trending left-lateral strike-slip faults and NW-SE trending discontinuities. The general extension of discontinuities is perpendicular to the faulting direction indicated by evaluation of the caves with the digital elevation model and lineament analysis. Findings of this investigation suggest that differences in the periodic development of the stalagmites are mainly due to tectonic movements. Therefore, the times of the growth-axis angle deviations for representative stalagmite samples from the Sakarlak Ponor and Kepez Cave were determined by U/Th analyses. The results tend to significantly overlap with times of historical earthquakes.
\end{abstract}

\section{INTRODUCTION}

A stalagmite is a type of speleothem or cave deposit usually consisting of calcium carbonate that grows upward from the dripping water, and forms over a very long time. Therefore well-developed and protected stalagmites allow us to obtain a fairly long record of seismicity of a region. In recent years, this topic has increasingly gained interest of researchers and been the subject to many studies (e.g., Ford and Hill, 1999; Gilli, 1999; Forti, 2001; Angelova et al., 2003; Gilli, 2005; Becker et al., 2006; Gunn, 2006; Šebela, 2008; Garduño-Monroy et al., 2011). In longitudinal sections of stalagmites, a sudden change in growth orientation is taken as evidence of possible paleoseismic activity (Postpischl et al., 1991; Forti, 2001; Gilli, 2005; Šebela, 2008). In fact, deviations from vertical growth of stalagmites can be due to seismic activity, glacial intrusion, or anthropogenic impact. For this reason, as a priority, paleoseismology studies have attempted to determine the causes of the deviations.

Throughout the history of humanity, caves have been used for various purposes, such as shelter, protection, hunting bases, or faith centers. Therefore, deformations like breakage, tipping, drying, or fracturing in cave sediments have been largely human effects. In addition, vibrations caused by blasting and heavy duty vehicles caused by nearby mining can also lead to deformations in the cave sediments. Another source of deformations in speleothems is considered to be glacial intrusion. Spötl and Mangini (2007) reported that glacial intrusion caused the breakage of speleothems in Snežna Jama Cave. Glacial notches and remains of moraine deposits are generally sought on the cave wall and floor as evidence of glacial intrusion. However, the effects of glacial intrusion on caves, their hydrology, and internal atmospheric conditions are not known (Šebela, 2008). So paleoseismic studies require elimination of the other effects on stalagmite deformation. Deviations of the stalagmite growth axis provide fairly good data for paleoseismological work. Forti's investigation (2001) regarding different tectonic effects on stalagmites accepted them as a proof for paleoseismic activities. In addition, Bayarı and Özyurt (2005) point out that those stalagmite growth axis-changes depend on the changes of the primary stalagmite position with time caused by tectonic raise or subsidence of the region.

This study aims to determine deviations of the growthaxis angle in the stalagmite samples and their age by U/Th (uranium/thorium) analysis and to correlate them with the paleoseismological record.

\section{Description of the Study Area}

Turkey is a fairly rich country with respect to karstification, and about $40 \%$ of its surface area is covered by carbonate rocks. In southern Turkey, the Tauride Mountains (also called Torid) consist mostly of platform carbonates deposited during Palaeozoic to Cenozoic. The study area is located in the central part of Taurides between the Lamas Canyon/Erdemli and the Göksu Valley/Silifke in the Mersin province (Fig. 1), where karstification is widespread. In the area, karst has been developed in carbonates at the edges of the Taurus Mountains, where hundreds of caves can be found with different features and formation histories. Almost all of the caves in the study area are located within early to middle Miocene reefal limestone, the Karaisalı Formation consisting of gray- to beige-colored, medium- to thick-bedded limestone containing lots of reef-forming organisms such as coral and red alga, and also molluscs, bryozoans, and echinoderms (Eren et al., 2004; Eren 2008; Alan et al., 2011). In places, these limestones are highly fractured, and the fractures are generally filled with calcite.

\footnotetext{
${ }^{1}$ MTA- General Directorate Of Mineral Research And Exploration, TR-06800 Ankara, Turkey, murat_akgoz@yahoo.com

${ }^{2}$ Department of Geological Engineering, Mersin University, TR-33343 Mersin, Turkey
} 


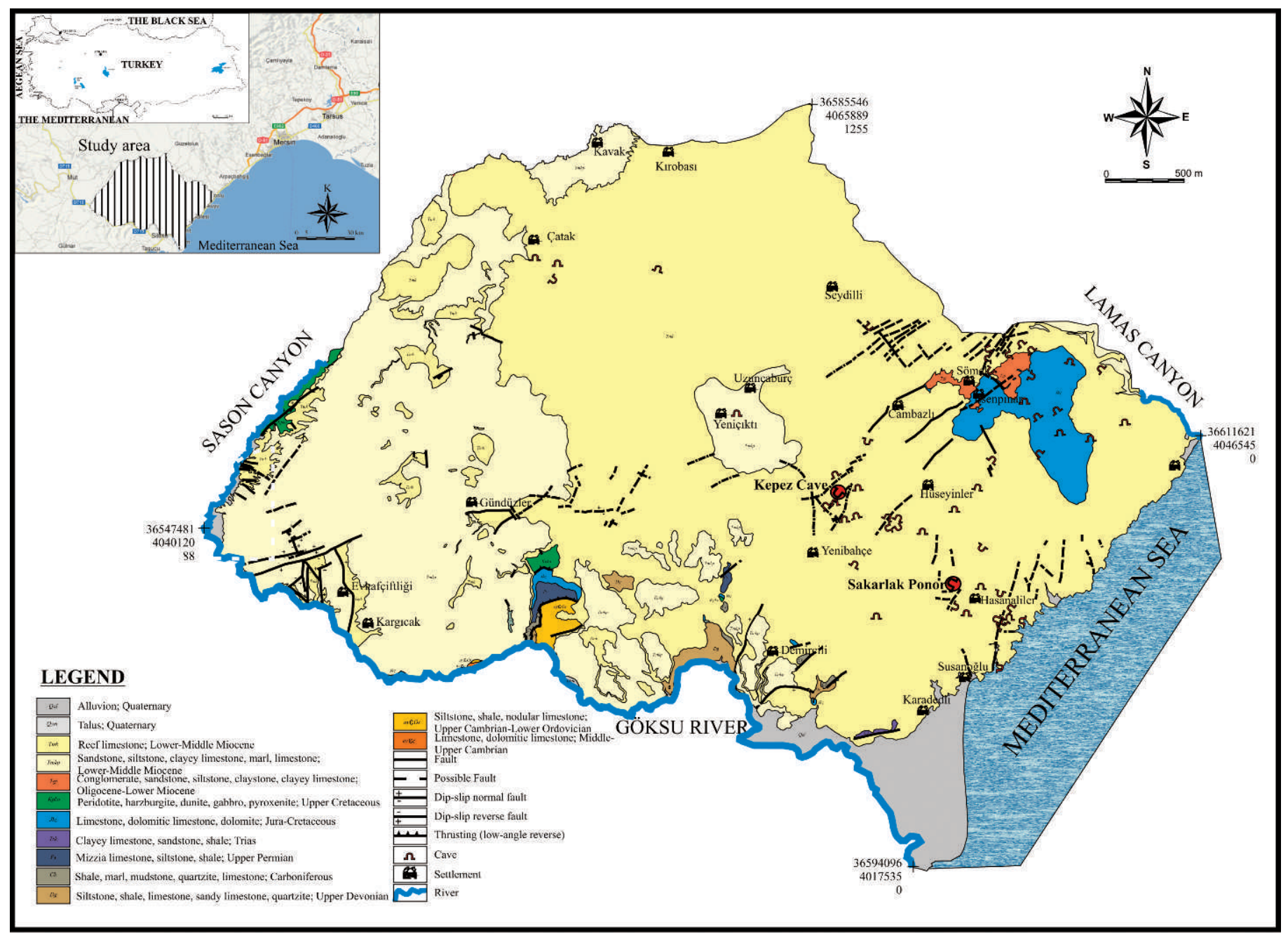

Figure 1. Geological map of the study area, with the locations of sample sites Sakarlak Ponor and Kepez Cave. The inset shows the location of the area within Turkey.

One of the most important things that have affected the karstification pattern is tectonic structure. In the area, karstification probably started after emergence of the central Taurus due to epeirogenetic raise at the end of Miocene. Following the middle Miocene, karstification in the region must have deepened due to dry and hot climate. This period is called the Messinian Salinity Crisis. Demirkol (1986) stated that the upper Miocene to Pliocene tectonic development of the region formed under a compressional regime. After these tectonic changes, NNW-SSE trending folds and reverse faults were formed. In addition, the region was affected by the ENE and WSW directed compression as the westward-moving Anatolian plate probably encountered great resistance in the Agean region. On the other hand, Akay and Uysal (1988) reported that the region was later subjected to only ineffective compression during the upper Pliocene. At the later stages, the region was affected by N-S compression. Today, the region continues to be under N-S directional compression and continues to rise as a block. With sea level changes in the
Mediterranean Sea during the upper Pliocene, the elevation of karstification started to decrease, and rapid development was caused by the NW-SE trending discontinuities. As a result, caves of multiple periods and stages were developed with youthful features such as canyons that are parallel to the NW-SE trending discontinuities. At the same time, these caves are evidence for regional uplift due to tectonic movements and change of the morphological base level due to climatic changes.

Most of the studied caves are well-developed vertical caves in cross-section. The vertical caves occur in areas where the base level of cave development is ambiguous or deep, characteristic of a young uplifted region (Ozansoy and Mengi 2006). However six caves with a mixture of horizontal and vertical development shows that the region was tectonically active (Garašić, 1991; Akgöz, 2012). In the region, orientation of surface karst features and the distribution of caves show consistency with distinct tectonic lines, which indicates the effect of tectonics on karstification. The orientations of the main faults and lineaments were 


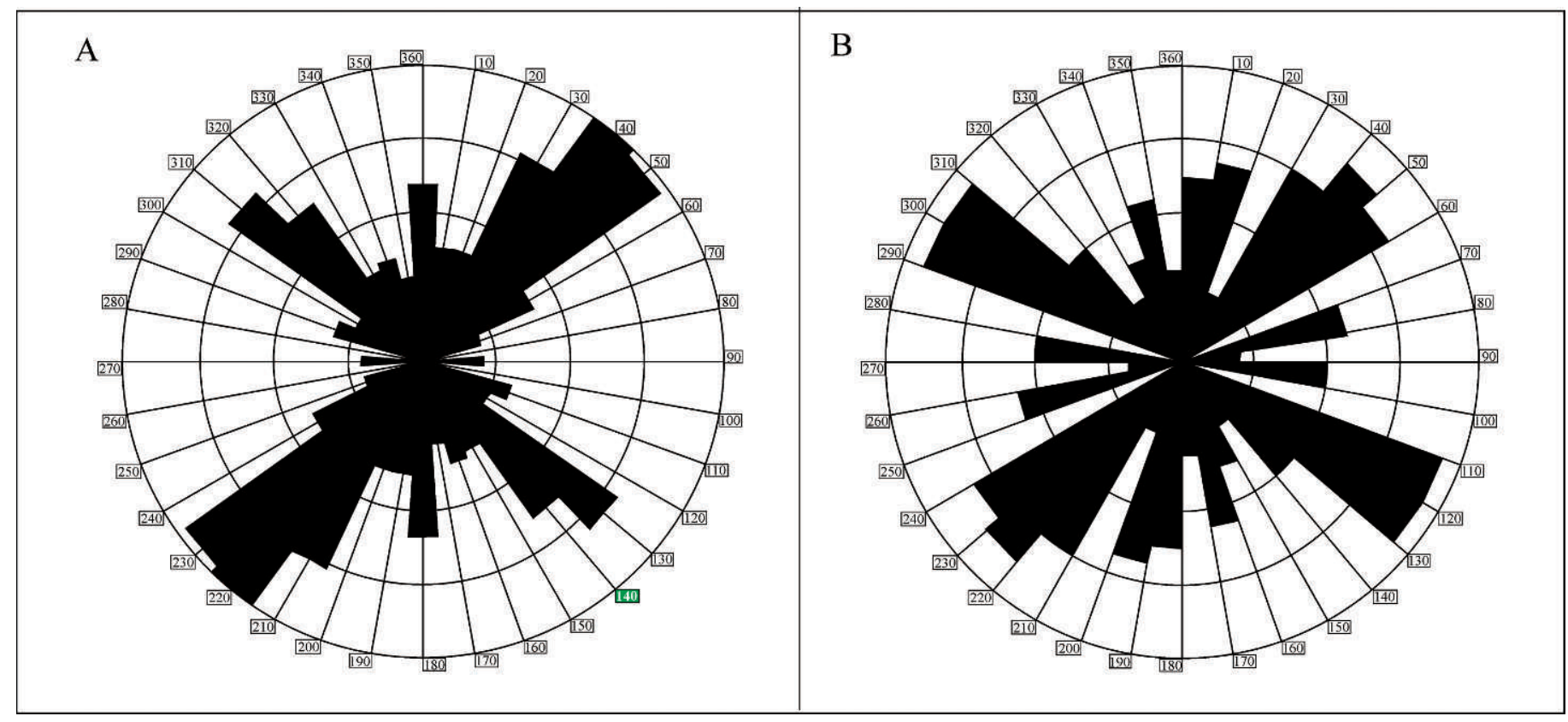

Figure 2. Rose diagrams showing (A) orientations of the main faults and lineaments obtained from digital elevation model of the study area and (B) the long axis-orientation of caves in the study area.

measured on a digital elevation model (Fig. 2A), and horizontal directions of cave passages were plotted (Fig. 2B). It is clearly seen that the directions of faults and discontinuities in the region are exactly compatible with the orientations of the caves. The majority of the caves were developed in the NW-SE direction. On the other hand, if their development started at NE-SW direction, then new branches were formed along NW-SE trending discontinuities that caused changes in direction of the cave development.

\section{SAKARlak Ponor}

The Sakarlak Ponor is a sinkhole formed by collapse of a cave roof. It is located in the bottom of a blind valley running N-S (Fig. 3). The original entrance to the ponor must have been at a lower elevation to serve as a drain for the valley. One of the characteristic features of blind valleys is that the valley ends downstream in either a sinkhole or a cave. Two sinkholes located to the south of the Sakarlak Ponor in the same valley may indicate former ponors at the end of the valley, with northward migration of the end point over a period of time (Fig. 3B). The cave developed within reef limestone and consists of a main gallery and a fossil branch indicating a multi-stage development (Fig. 4). The main gallery of the ponor occurred along NW-SE trending discontinuities, whereas the fossil branch extends parallel to the NE-SW trending main tectonic line.

At the junction point of the main gallery with the fossil branch, there are numerous fallen columns and stalagmites (Fig. 5). Here displacement must have been caused by possible collapse and tectonic depression during the ponor's development, because of its hard-to-access position with a depth of 51 meters. In the Sakarlak Ponor, episodic mud flows inhibited stalagmite development except in some protected areas showing well developed primary and secondary stalagmites (Fig. 6).

\section{KePez Cave}

The Kepez Cave is in reef limestone and shows multiple stages of development. The cave, located on the edge of a doline (Fig. 3A), consists of the main gallery and lots of secondary branches. The Kepez Cave has a depth of 65 meters and a length of approximately 370 meters (Fig. 7). The cave branches extend parallel to NW-SE trending discontinuities, whereas the main gallery is parallel to the NE-SW trending tectonic line, with an average inclination of 45 degrees, and has a ceiling height up to 26 meters. The main gallery is fairly rich with speleothems. Some reach a height of up to 10 meters (Fig. 8). Initially, evolution of the main gallery parallel to main tectonic lines was interrupted by NW-SE trending discontinuities, where new branches emerged towards to the end of the gallery.

\section{Methods}

The most appropriate samples for paleoseismological studies are cylindrical stalagmites with uniform growth, because uniform stalagmites reflect formation under unchanged conditions, such as water amount and chemistry. Throughout the last three years, paleoseismological data were collected from the caves located in the southern Taurus Mountain. Three stalagmite samples used in this study were taken from two different caves, namely the 

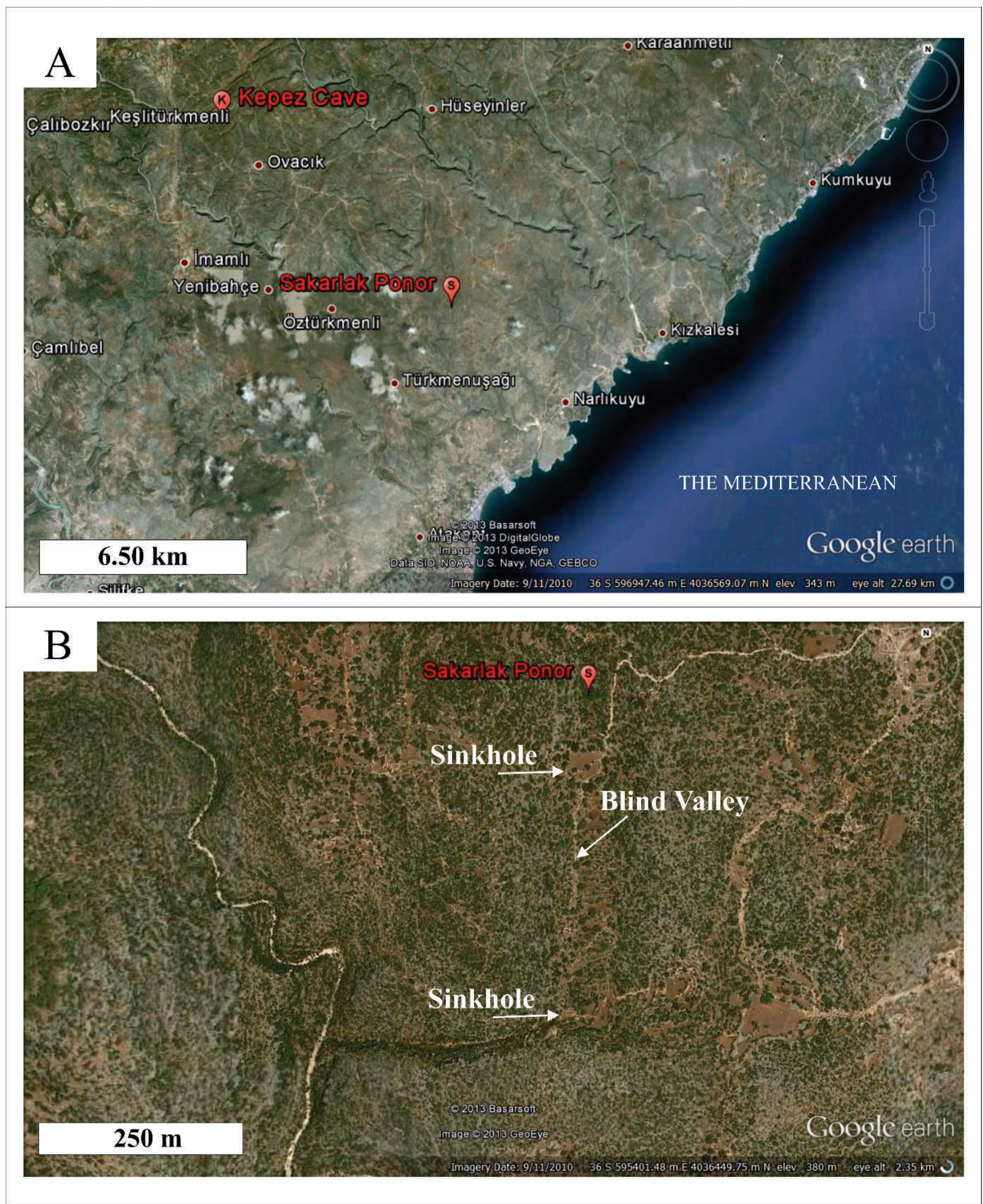

Figure 3. Satellite images from Google Earth showing locations of the Sakarlak Ponor and Kepez Cave (A) and an enlargement of the the Sakarlak Ponor area showing its relationship to the blind valley and two sinkholes (B). 


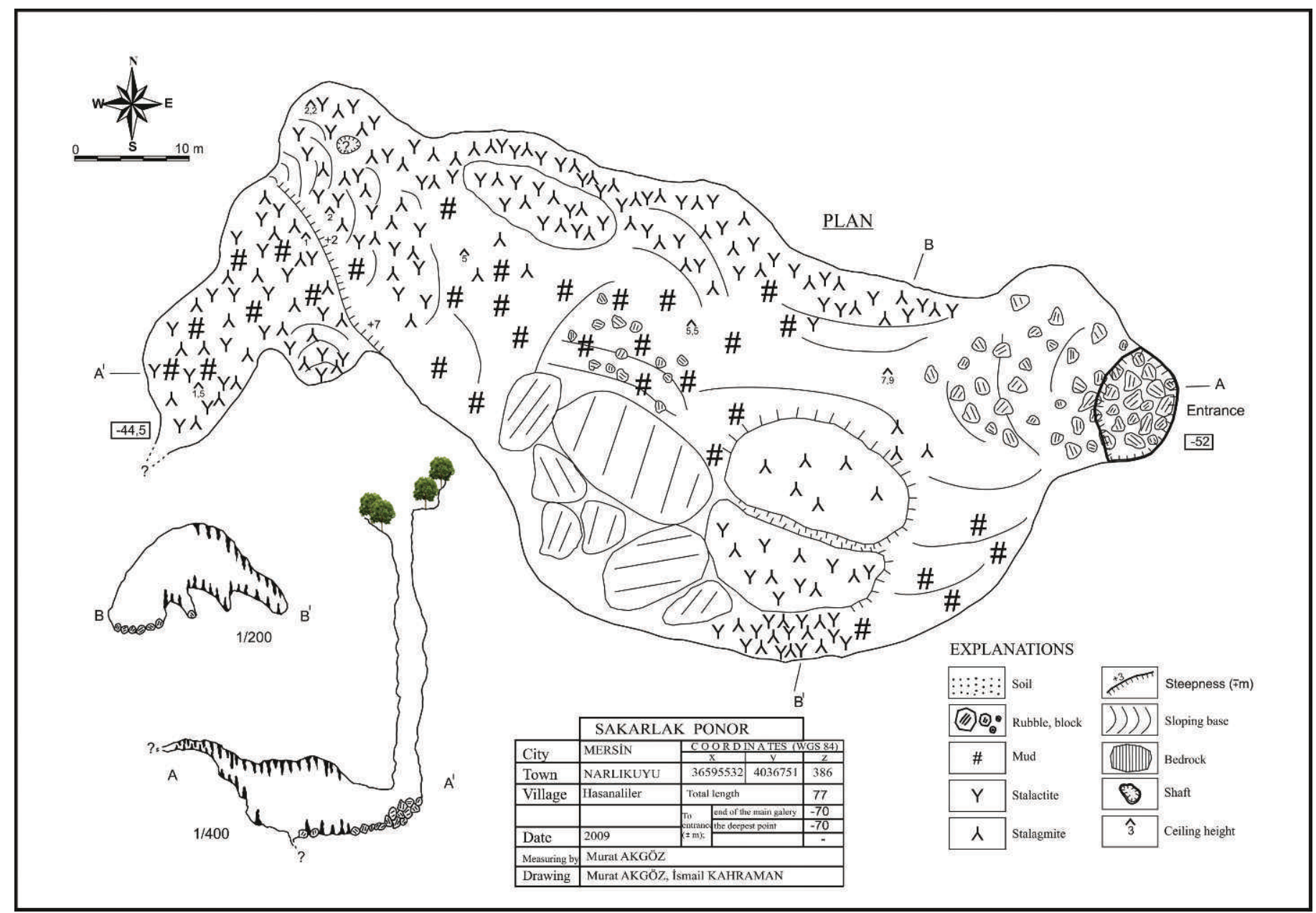

Figure 4. A plan map and cross-sections of the Sakarlak Ponor.

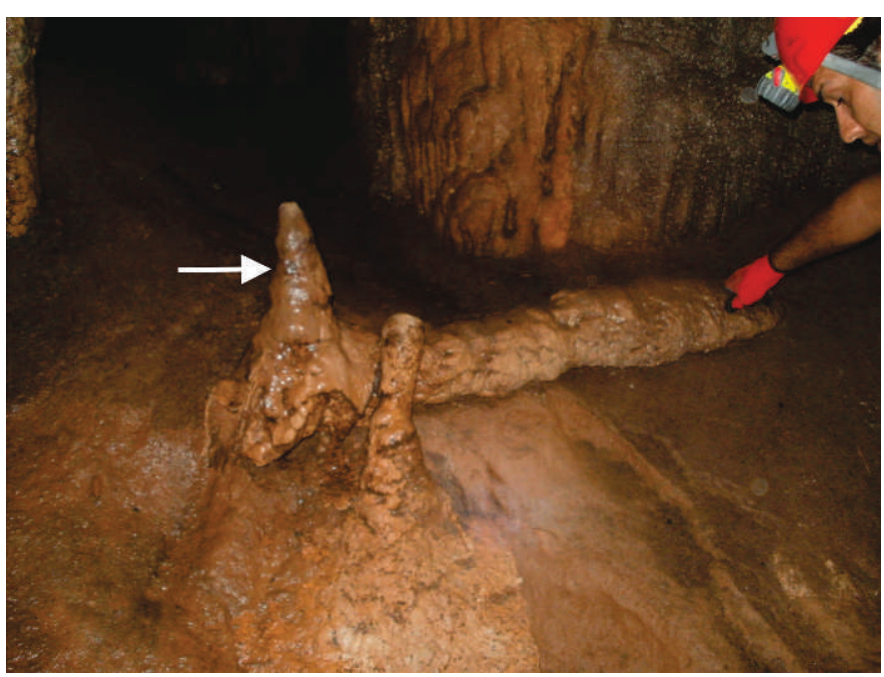

Figure 5. A fallen stalagmite with more recent stalagmites at the junction of the fossil passage and the main gallery in Sakarlak Ponor.
Sakarlak Ponor and Kepez Cave by using SRT (single rope technique) for access. The reason for selecting these locations is their protection from anthropogenic and glacial effects. The stalagmites were cut along the growth axes, then polished, examined under a binocular microscope for corrosive hiatuses, and dated using U/Th dating.

From each stalagmite, two distinctive samples from the top and bottom portions of the stalagmite were taken by dental drilling to determine U/Th age for deviations in the growth axis angle. After the Hendy Test determining dateable ${ }^{230} \mathrm{Th}$ mineral in the samples, the U/Th analyses were performed using the high-precision mass spectrometry at the Environment Change Laboratory (HISPEC) of the National Taiwan University. In general, U samples are low levels and a large part of the samples in the range of 90 to $182 \mathrm{ppb}$ (Table 1). Ages in Table 1 were calculated in the standard way.

\section{RESUlts}

SAKARLAK 4

The sample S4 was taken from the southern side of the main gallery, where numerous large blocks have collapsed

Journal of Cave and Karst Studies, April 2015•67 


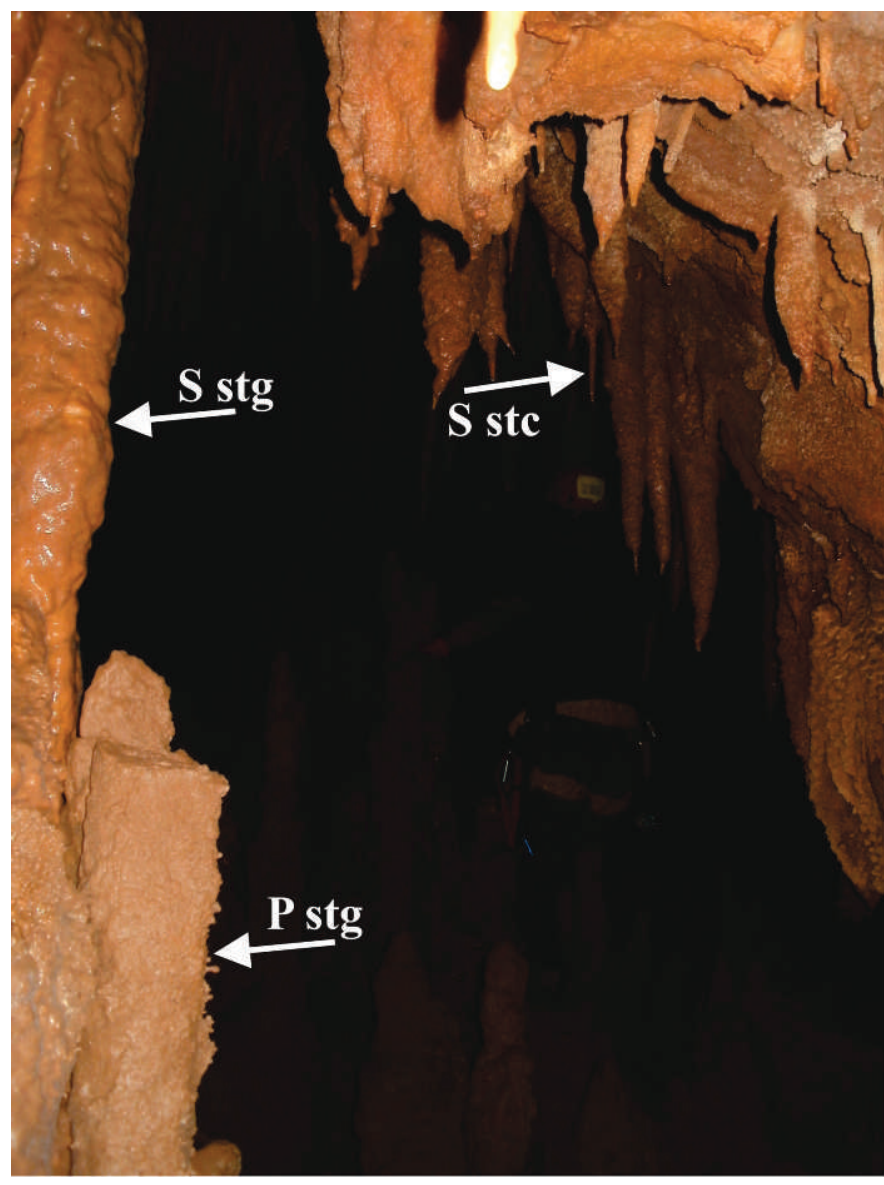

Figure 6. Primary (P) and Secondary (S) stalactites (stc) and stalagmites (stg) in the Sakarlak Ponor.

from the cave ceiling. The sample $\mathrm{S} 4$ has a length of $32.3 \mathrm{~cm}$, with base and tip diameters of 11.1 and $3.8 \mathrm{~cm}$ (Fig. 9) respectively. The deposition rate changes with amount of water, water flow type, and content of carbon dioxide. Therefore, diameter changes in a stalagmite indicate fluctuation in water supply. Stalagmite S4 consists of dark and light colored laminae, and in some cases, gaps are present between these laminae. In general, such gaps occur through evaporation due to temperature rise, loss of moisture, and air circulation (Boch, 2008; Meyer et al., 2008).

For the formation time of $\mathrm{S} 4, \mathrm{U} / \mathrm{Th}$ age determination was performed on two different parts of sample using MCICPMS technique. Based on age determinations, sample age of the base and the tip portions were determined $780 \pm$ 919 and $775 \pm 2732$ years, respectively. For S4, the average growth rate was estimated from ratio of time difference to the distance between the sampling points. This rate for uniformly developed stalagmite is $1.25 \mathrm{~mm}$ for each year. This value is not within the range of $0.015 \mathrm{~mm}$ and $0.37 \mathrm{~mm}$ for each year reported in the literature (Fairchild et al., 2010; Fleitmann et al., 2004; Frisia et al., 2003; Genty et al., 2001; Polyak and Asmeron, 2001; Treble et al., 2003;
White, 2007). This may be explained by differences in the growth rate of stalagmites, as well as variety in their structure, texture, and chemical composition. The stalagmite sample was formed over approximately 258 years between $\mathrm{AD} 55$ and $\mathrm{AD}$ 313. This time interval remains within the specified period in a general upward trend the global air temperature between $\mathrm{AD} 0$ and 1000, as is known from various climate indicators such as tree rings, lake sediments, and cave deposits (Şenoğlu, 2006).

Deviations of growth axis angle are in keeping to a very large extent with the historical earthquake times. A comparison of the occurrence time of historical earthquakes in the literature with predicted ages for growth axis angle deviations provides a possible evidence for earthquakes. The margin of error between historical earthquakes and predicted years about deviation of the growth axis angles is maximum 5 years. Stalagmite growth axis angle deviation of approximately 16 degrees corresponds to year AD 115 (Fig. 9). This date coincides with the AD 110 and AD 115 Antioch Earthquakes in literature (Altınok et al., 2011; Erel and Adatepe, 2007; Sbeinati et al., 2005). In the same literature, it is specified that the intensities of AD 110 and AD 115 Antioch Earthquakes were respectively 8 and 9 , and 260,000 people died as a result of these earthquakes. In a modeling of the historical tsunami with a tectonic origin in the Mediterranean, tsunami waves reached to south coast of Turkey in one hour after a magnitude 8 earthquake in Helenic Arc, and the south coast of Turkey was strongly affected by tsunami waves (Tinti et al., 2005). Similarly, relatively small deviations of the growth axis angle and the differences in the lamina thickness and color seen in the stalagmite tip are largely consistent with historical earthquakes. These earthquakes, AD 334 Antioch, AD 341 Antioch, AD 344 Rhodes, and AD 365 Cyprus, had intensities of 9, 8, 9, and 9, respectively (Antonopoulos, 1980; Pararas-Carayannis, 2011; Erel and Adatepe, 2007; Papadopoulos et al., 2007; Sbeinati et al., 2005; Soloviev et al., 2000; Tinti et al., 2005). In literature, Rhodes was largely collapsed as a result of Rhodes Earthquake in AD 344. In addition, there were approximately $9 \mathrm{~m}$ high tsunami waves in the Mediterranean after the Cyprus and Crete Earthquake in AD 365 (Erel and Adatepe, 2007). Data for the Sakarlak 4 sample are a very good example of the effects of seismic activity on aspects of stalagmite development such as growth-axis angle and thickness and color differences of laminae. These changes are records of past earthquakes, and hence, they are very useful data for the study of cave sediments for paleoseismology.

\section{SAKARLAK 1}

The sample Sakarlak 1 was taken at the junction of the main gallery and fossil branch in the nothwestern part of the main gallery. The stalagmite S1 developed uniformly and has a length of $29.8 \mathrm{~cm}$. During its development, the average diameter of approximately $5 \mathrm{~cm}$ remained 


\begin{tabular}{|c|c|c|c|c|}
\hline & \multicolumn{3}{|c|}{ KEPEZ CAVE } & \\
\hline City & MERSIN & $\frac{\operatorname{COORP}}{x}$ & $\frac{\text { INATES }(1)}{y}$ & $\frac{1}{\left.\frac{1(G S}{2} 84\right)}$ \\
\hline Town & SILIFKE & 36595532 & 4036751 & 386 \\
\hline Village & Keşlitürkmen & \multicolumn{2}{|c|}{ Total length $(\mathrm{m})$} & 366,8 \\
\hline & & To End of & dend of the main galcry & \begin{tabular}{|l|}
$-63,8$ \\
-656 \\
\end{tabular} \\
\hline Date & 2009 & 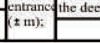 & & $-65,6$ \\
\hline Measuring $\mathrm{b}$ & \multicolumn{4}{|c|}{\begin{tabular}{|l} 
Murat AKGÖZ, İsmail KAHRAMAN \\
\end{tabular}} \\
\hline Drawing & \multicolumn{4}{|c|}{\begin{tabular}{|l|} 
Murat $A K G O ̈ Z Z$ \\
\end{tabular}} \\
\hline
\end{tabular}

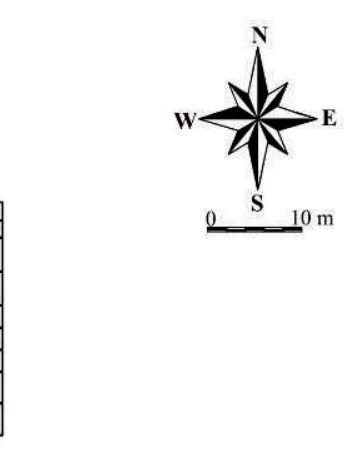

Entrance
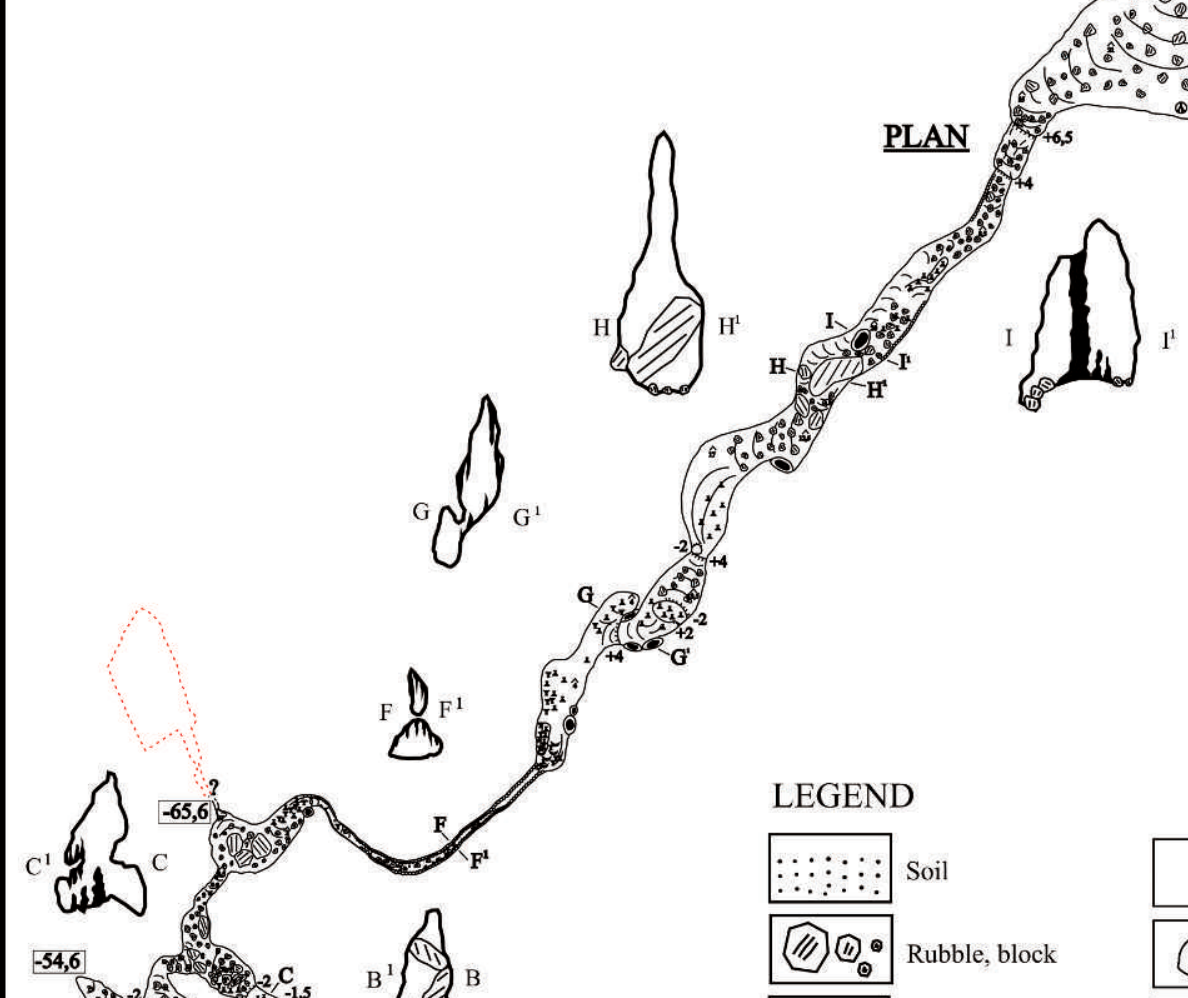

LEGEND

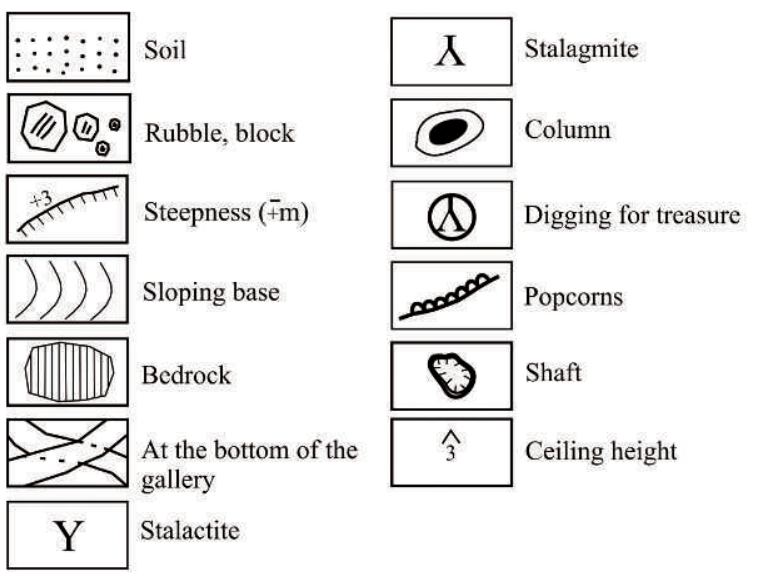

*section scales $1 / 400$

Figure 7. A plan map and cross-sections of Kepez Cave. 


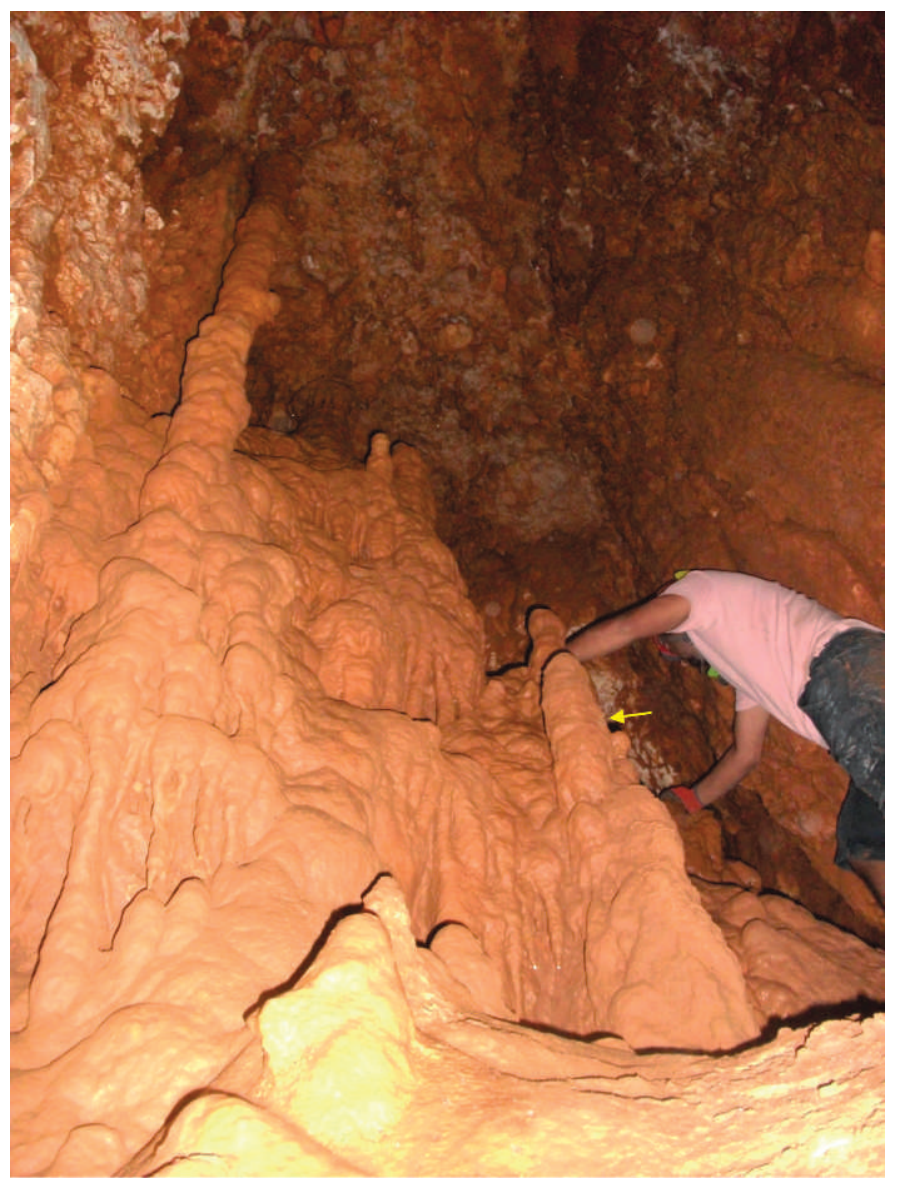

Figure 8. Mud-covered speleothems in the Kepez Cave.

unchanged. The unchanged diameter shows that there is no significant change in the amount of dripping water that fed this stalagmite.

The longitudinal cross-section of S1 revealed, especially at the end portion the stalagmite, laminae with different thicknesses and color. This part of the stalagmite also shows a different growth axis (Fig. 10). Stalagmite growthaxis angle changes and differences between laminae in sediment were caused by tectonic effects and settlement and collapse of the cave during precipitation.

For the formation time of S1, U/Th age was determined from two different parts of sample using MC-ICPMS technique. Based on these determinations, sample ages of the base and tip portions are 65,929 \pm 337 and 56,439 \pm 517 years, respectively. For S1, the average growth rate was calculated from time difference and distance between the sampling points. The stalagmite shows a uniform development with a growth rate of $0.03 \mathrm{~mm}$ for each year. This value is within the range of $0.015 \mathrm{~mm}$ and $0.37 \mathrm{~mm}$ for each year given in literature (Genty et al., 2001; Polyak and Asmeron, 2001; Frisia et al, 2003; Treble et al., 2003; Fleitmann et al., 2004; White, 2007; Fairchild et al., 2010). Considering the average growth rate, we concluded that the sample was formed over 9310 years during the Pleistocene.
Figure 10 shows the deviations of the stalagmite growthaxis angle labeled with times determined by taking into account the color and sedimentary changes between laminae, the average growth rate, and the sample length. The most significant deviation of the growth axis angle of stalagmite occurred approximately $61 \pm 0.5 \mathrm{ka}$ years ago, when there was a sudden deviation of 26 degrees in the growth caused by seismic activities (Fig. 10). Values of subsequent deviations in the growth axis range from 12 to 15 degrees. However, it is difficult to determine the causes of the deviations. Their occurrence is probably due to seismic activity or settling and subsidence of the floor of the cave. The view of the stalagmite was taken out of a collapsed block. About $56 \pm 0.5$ ka years before present, a stalagmite growth-axis deviation of about 21 degrees was due to tectonic activities rather than settling or subsidence in the cave. The conclusion is based on the difference in the color of the deposit during approximately 156 years, based on the length of the lamina and the average growth rate. During the formation of this stalagmite, climatic oscillation is characterized by changes in carbonate sediment color. Darkcolored laminae rich in organic matter (Fig. 10) indicate deposition during period of relatively abundant vegetation (Bradley, 1999 p. 326-335; Van Beynen et al., 2004; Bayarı and Özyurt, 2005; Webster et al., 2007; White, 2007; Meyer et al., 2008; Fairchild et al., 2010). Feed-water from which the stalagmite formed had more organic substance after passing through the soil zone due to more intense organic activities. Therefore, these dark-colored laminae indicate stalagmite development under a temperate or warm climate, whereas the light-colored laminae are poor in organic material and indicate relatively cold climatic conditions.

According to U/Th age determination, the Sakarlak 1 stalagmite was formed during the Pleistocene. According to the literature, during the period of about 9,000 to 90,000 years before the Holocene, a large part of the European continent was covered with ice having a thickness up to $3 \mathrm{~km}$. During this time period, there was a climatic fluctuation characterized with long-term cooling and short-term warming periods that would cause color variations in stalagmites (Altın, 2007).

\section{Sample of Kepez Cave}

The sample from Kepez Cave was taken from the first point of intersection of a side branch with the main gallery (Fig. 7). The sample has a length of $16 \mathrm{~cm}$, and its base and tip diameters are 7.2 and $3.5 \mathrm{~cm}$, respectively (Fig. 11). In general, the stalagmite shows regular vertical diameter changes along the growth axis. However, narrowing in diameter is observed at four different points. Possible causes of these diameter narrowing's in the stalagmite are changes in the amount of water feeding it, interruption of the dripping water due to tectonic movements, and seasonal cold and dry climatic conditions.

$\mathrm{U} / \mathrm{Th}$ ages from two different parts of the sample from Kepez Cave were determined using MC-ICPMS technique. 
Table 1. $\mathrm{U}$ and Th isotope composition of the stalagmite samples and their ${ }^{230} \mathrm{Th}$ ages.

\begin{tabular}{lccc}
\hline & & I.D. & Kepez \\
\cline { 2 - 3 } Isotope & Sakarlak 1 & Sakarlak 4 & \\
\hline${ }^{238} \mathrm{U}$, ppb & & & $182.01 \pm 0.17$ \\
Sample 1 & $97.99 \pm 0.11$ & $57.399 \pm 0.045$ & $48.940 \pm 0.051$ \\
Sample 2 & $94.499 \pm 0.069$ & $58.414 \pm 0.053$ & $755 \pm 18$ \\
${ }^{232}$ Th, ppt & & & $485 \pm 9.1$ \\
Sample 1 & $2963 \pm 16$ & $5237 \pm 15$ & \\
Sample 2 & $544 \pm 10$ & $15285 \pm 75$ & $97.4 \pm 1.5$ \\
$\delta^{234}$ U, measured & & & $112.1 \pm 1.9$ \\
Sample 1 & $335.7 \pm 2.4$ & $340.9 \pm 1.7$ & $31787 \pm 188$ \\
Sample 2 & $330.2 \pm 1.8$ & & $58784 \pm 426$ \\
Age, uncorrected & & $2593 \pm 88$ & \\
Sample 1 & $57015 \pm 432$ & $4520 \pm 281$ & $31688 \pm 194$ \\
Sample 2 & $66038 \pm 333$ & & $58552 \pm 441$ \\
Age, corrected & & $780 \pm 919$ & \\
Sample 1 & $56439 \pm 517$ & $775 \pm 2732$ & $106.6 \pm 1.7$ \\
Sample 2 & $65929 \pm 337$ & & $132.3 \pm 2.3$ \\
${ }^{234} U_{\text {initial }}$ corrected & & $341.6 \pm 1.9$ & $336.9 \pm 3.3$ \\
Sample 1 & $393.7 \pm 2.8$ & & \\
Sample 2 & $397.8 \pm 2.2$ & & \\
\hline
\end{tabular}

Note: Analytical errors are $2 \sigma$ of the mean. ${ }^{234} \mathrm{U}_{\text {initial }}$ corrected was calculated based on ${ }^{230} \mathrm{Th}$ age $(\mathrm{T})$ (i.e., $\mathrm{d}^{234} \mathrm{U}_{\text {initial }}=\mathrm{d}^{234} \mathrm{U}_{\text {measured }} X \mathrm{e}^{1234^{*} \mathrm{~T}}$, and $\mathrm{T}$ is corrected age); ppb $=$ parts per billion; ppt $=$ parts per trillion.

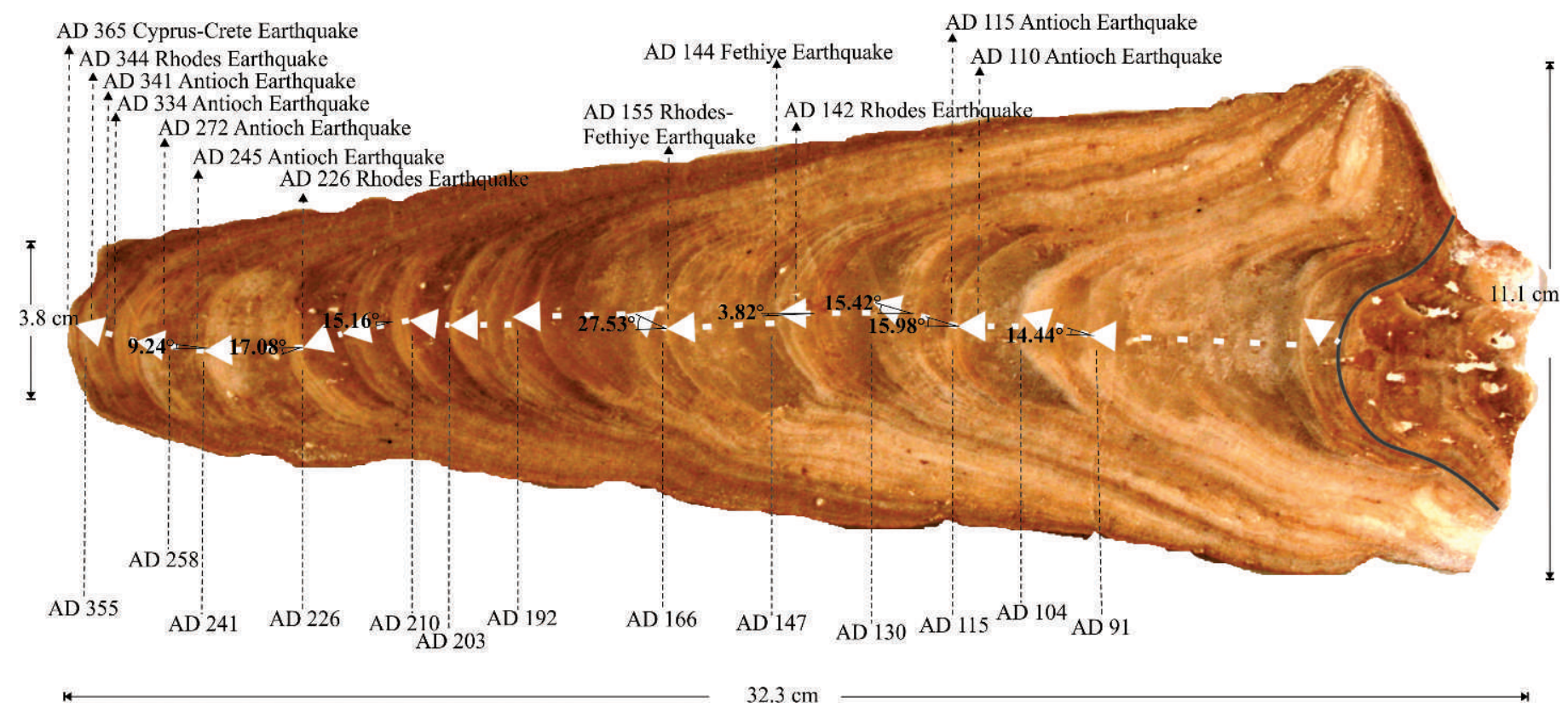

Figure 9. Longitudinal section of the Sakarlak 4 sample showing deviations in the growth-axis angle. Dates of the deviations are derived by interpolating between the dates locations. Historic earthquakes known to have occurred in the area are also indicated. 


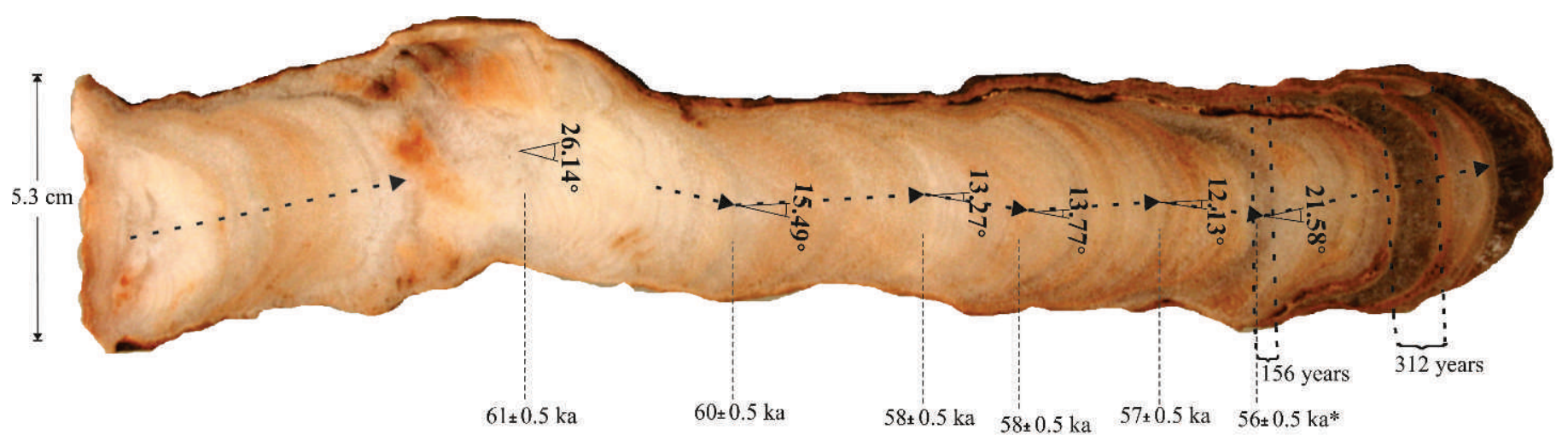

$*(1 \mathrm{ka}=1000$ calendar years, ago $)$

$29.8 \mathrm{~cm}$

Figure 10. Longitudinal section of the Sakarlak 1 sample showing deviations in the growth axis angle, with corresponding ages.

The ages of the base and tip portions of the stalagmite are $31,688 \pm 194$ and $58,552 \pm 441$ years, respectively. The average growth rate calculated from the time difference and the distance between the sampling points is $0.006 \mathrm{~mm}$ for each year for the stalagmite. This value is not within the range of $0.015 \mathrm{~mm}$ and $0.37 \mathrm{~mm}$ for each year (Genty et al., 2001; Polyak and Asmeron, 2001; Frisia et al., 2003; Treble et al., 2003; Fleitmann et al., 2004; White, 2007; Fairchild et al., 2010). The growth rates of stalagmites, as well as their structures, textures, and chemical compositions, may differ. The stalagmite was slowly formed during a time of about $27 \mathrm{ka}$ years toward the end of the Pleistocene based on average growth rate, the distance between the dated points, and the total length of the stalagmite. As mentioned before, the majority of the European continent was under a thick layer of glacial ice at this time. Warm periods were shorter than the periods of cooling. In the longitudinal cross-section of the Kepez sample, light-colored laminae are poor in organic matter, whereas dark-colored laminae are enriched in organic matter due to rapid change in climate during warm periods (Bradley, 1999 p. 326-335; Van Beynen et al., 2004; Bayarı and Özyurt, 2005; Webster et al., 2007; White, 2007; Meyer et al., 2008; Fairchild et al., 2010). As a result of these data, it could be said that the light-colored deposition showing the cooling period in climatic fluctuation repeated approximately 49,410 years ago, and also in climate fluctuation warming was repeated during a period of about 43,493 years before present (Fig. 11).

In the longitudinal cross-section of the Kepez Cave stalagmite, there are three different deviations of the stalagmite growth axis. The clearest deviation of the

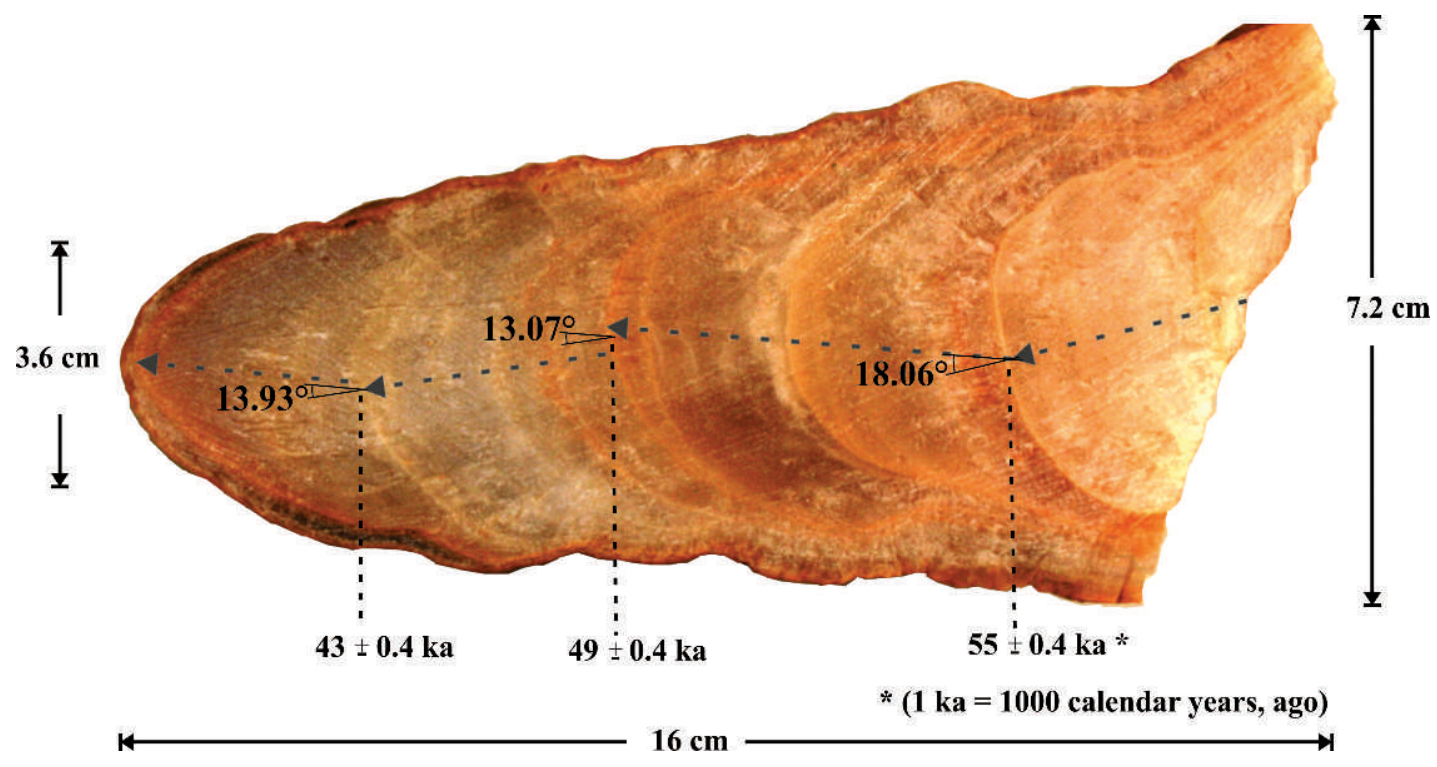

Figure 11. Longitudinal section of the Kepez Cave sample showing deviations in the growth axis angle and approximate ages. 
growth axis angle is about 18 degrees and occurred $55 \pm$ $0.5 \mathrm{ka}$ ago. This value could be correlated with the Sakarlak Ponor sample 1, located approximately $9 \mathrm{~km}$ from the southwest of the Kepez Cave. Considering the S1 age data and the margins of error, this deviation could be caused by the same seismic activities that led to its growthaxis change of 21 degrees. Except for the clearest deviation of the growth axis in the Kepez sample, the other two deviations of 13 and 14 degrees occurred at different times (Fig. 11). These data, in addition to the thickness and color differences among laminae in the sample from Kepez Cave, indicate that the Kepez Cave was affected by seismic activity at three different times.

\section{CONClusions}

Caves in the study area are clearly developed on the fault, fracture, and crack systems. According to the lineament map generated from the digital elevation model, the main tectonic line is a NE-SW-trending left-lateral strike-slip fault. On the other hand, parts of the caves are parallel to NW-SE-trending discontinuities that are perpendicular to the main tectonic line. Karstification in the central Taurus Mountains and also in the study area began to develop at the transition from Pliocene to Pleistocene. The NW-SE trending discontinuities and the warm climatic intervals within the Pleistocene glacial periods have affected karstification and cave development in the region.

The U/Th analyses indicate low levels of $U$ in the samples. Lamina thickness and color changes of the selected samples were examined together to determine changes of the stalagmite growth-axis angles, these changes are possibly due to seismic activity.

According to U/Th age data, the selected stalagmites were formed in the Pleistocene to Holocene. The S1 sample from the Sakarlak Ponor was developed over 9310 years during Pleistocene. During this time, the growth axis of the stalagmite has changed six times. The Kepez Cave sample was developed slowly over a time of about $27 \mathrm{ka}$ in the Pleistocene during which the stalagmite's growth-axis position changed at three distinct times. The largest deviation times of growth axis angle for the Kepez Cave and Sakarlak 1 samples are 18 and 21 degrees, respectively. These deviation angles are very close to each other indicating that two samples were affected by the same seismic activities. On the other hand, periods of the darkcolored laminae in the sample reflect interglacial periods in Pleistocene. Based on the U/Th analytical results of the selected samples, the youngest dates belong to the Sakarlak 4 sample. When average growth rate, the distance between sampling points, and the U/Th age data of the sample S4 were evaluated together, the sample shows a rapid growth in a range of about 258 years between the years AD 55 and AD 313. In this time interval there was a tendency to an overall increase in global air temperature.
The deviation times of the stalagmite growth-axis angles are largely compatible with the times of historical earthquakes. The determined time of AD $115 \mathrm{yr}$ for the S4 16 degree growth axis deviation corresponds to the magnitude 8 earthquake AD 110 or magnitude 9 earthquake AD 115 Antioch Earthquakes that caused the death of thousands of people. The deviation of 4 degrees having a formation time of AD 147 coincides with AD 142 Rhodes or AD 144 Fethiye magnitude 8 earthquakes. Ages of deviations with 17 and 9 degrees were determined as AD 226 and AD 241, respectively. These ages are coincident with the magnitude 8 earthquakes AD 226 Rhodes and AD 245 Antioch. In addition, lamina thickness and color differences near the tip of the stalagmite sample coincident with deviations of the growth-axis angle are thought to be coincident with magnitude 8 AD 334 and magnitude 9 AD 341 Antioch earthquakes, the magnitude 9 AD 344 Rhodes earthquake, which was largely caused by the collapse of Rhodes, or the AD 364 Cyprus-Crete earthquake.

In conclusion, dating deviations of the growth-axis angle in stalagmites provides information on growth deformation and development. These ages can be correlated with occurrence time of historical earthquakes, suggesting possible effects of earthquakes on stalagmite development.

\section{ACKNOwledgements}

The authors are thankful to Prof. Dr. Chuan Chou Shen (the National Taiwan University) for his valuable suggestions about U/Th dating. This paper is based on a part of the first author's dissertation, which was supervised by second author. Mersin University Research Fund financially supported this research under the project of BAPFBE JM (MA) 2011-5 DR. The authors are much indebted to the anonymous reviewers for their extremely careful and constructive reviews that significantly improved the quality of the paper. Thanks are also due to Miss Sibel Kocaoğlan for language editing of the final text.

\section{REFERENCES}

Akay, E., and Uysal, Ş., 1988, Orta Toroslar'ın post-Eosen tektoniği: Maden Tetkik ve Arama Dergisi, v. 108, p. 57-68

Akgöz, M., 2012, Göksu nehri ve Lamas kanyonu (Mersin) arasında kalan bölgenin karst evrimi [Ph.D. thesis]: Mersin, Mersin Üniversitesi Fen Bilimleri Enstitüsü, 290 p.

Alan, İ., Şahin, Ş., Elibol, H., Keskin, H., Altun, İ., Bakırhan, B., Balcı, V., Böke, N., Kop, A., Esirtgen, T., and Hanilçi, N., 2011, Orta Torosların jeodinamik evrimi Bozyazı-Aydıncık-Gülnar-Silifke (İçel) yöresi: Ankara, Maden Tetkik ve Arama Raporu No: 11462, 308 p.

Altın, V., 2007, İklim dinamikleri: Bilim ve Teknik Dergisi, Şubat sayısı p. 2-4 (in Turkish).

Altınok, Y., Alpar, B., Özer, N., and Aykurt, H., 2011, Revision of the tsunami catalogue affecting Turkish coasts and surrounding regions: Natural Hazards and Earth System Sciences, v. 11, p. 273-291. doi:10.5194/nhess-11-273-2011.

Angelova, D., Belfoul, M.A., Bouzid, S., Filahi, M., and Faik, F., 2003, Paleoseismic phenomena in karst terrains in Bulgaria and Morocco: Acta Carsologica, v. 32, no. 1, p. 101-120. 
Antonopoulos, J., 1980, Data from investigation on seismic sea-waves events in the Eastern Mediterranean from the Birth of Christ to 500 A.D: Annali di Geofisica, v. 33, p. 141-161.

Bayarı, S., and ve Özyurt, N., 2005, Mağara çökellerinden geçmiş ortam koşullarının belirlenmesi: Konya, Ulusal Mağara Günleri Sempozyumu, p. 19-29.

Becker, A., Davenport, C.A., Eichenberger, U., Gilli, E., Jeannin, P.-Y., and Lacave, C., 2006, Speleoseismology: A critical perspective: Journal of Seismology, v. 10, p. 371-388. doi:10.1007/s10950-0069017-z.

Boch, R., 2008, Stalagmites from Katerloch Cave, Austria: Growth dynamics and high-resolution records of climate change [Ph.D. thesis]: Innsbruck, University of Innsbruck, 223 p.

Bradley, R.S., 1999, Paleoclimatology: Reconstructing Climates of the Quaternary, second edition, San Diego: Academic Press, International Geophysics Series no. 68, 613 p.

Cheng, H., Edwards, R.L., Hoff, J., Gallup, C.D., Richards, D.A., and Asmerom, Y., 2000, The half-lives of uranium-234 and thorium-230: Chemical Geology, v. 169, p. 17-33. doi:10.1016/S0009-2541(99) 00157-6.

Demirkol, C., 1986, Sultandağ ve dolayının tektoniği: Maden Tetkik ve Arama Dergisi, v. 107, p. 111-118.

Erel, T.L., and Adatepe, F., 2007, Traces of historical earthquakes in the ancient city life at the Mediterranean region: Journal of the Black Sea/ Mediterranean Environment, v. 13, p. 241-252.

Eren, M., 2008, Olba (Ura-Uğuralanı) jeoarkeolojisi (Silifke, Marsin), in Dönmez, H., and Özme, A., eds., Arkeometri Sonuçları Toplantısı: Ankara, Kültür ve Turizm Bakanlığı, no. 24, p. 181-192.

Eren, M., Kadir, S., Hatipoğlu, Z., and Gül, M., 2004, Mersin (İçel) Yöresinde Kaliş Gelişimi: TÜBITAK Project, No. 102Y036, 136 p. (in Turkish with English abstract).

Fairchild, I.J., Spötl, C., Frisia, S., Borsato, A., Susini, J., Wynn, P.M., Cauzid, J., Edinburgh Ion Microprobe Facility, 2010, Petrology and geochemistry of annually laminated stalagmites from an Alpine Cave (Obir, Austria): Seasonal cave physiology: Geological Society, London, Special Publications, v. 336, no. 1, p. 295-321. doi:10.1144/ SP336.16.

Fleitmann, D., Burns, S.J., Neff, U., Mudelsee, M., Mangini, A., and Matter, A., 2004, Palaeoclimatic interpretation of high-resolution oxygen isotope profiles derived from annually laminated speleothems from Southern Oman: Quaternary Science Reviews, v. 23, p. 935-945. doi:10.1016/j.quascirev.2003.06.019.

Ford, D.C., and Hill, C.A., 1999, Dating of speleothems in Kartchner Caverns, Arizona: Journal of Cave and Karst Studies, v. 61, no. 2, p. 84-88.

Frisia, S., Borsato, A., Preto, N., and McDermott, F., 2003, Late Holocene annual growth in three Alpine stalagmites records the influence of solar activity and the North Atlantic Oscillation on winter climate: Earth and Planetary Science Letters, v. 216, no. 3, p. 411-424. doi:10.1016/S0012-821X(03)00515-6.

Garašić, M., 1991, Morphological and hydrogeological classification of speleological structures (caves and pits) in the Croatian karst area: Geološki vjesnik, v. 44, p. 289-300.

Garduño-Monroy, V.H., Pérez-López, R., Rodríguez-Pascua, M.A., García-Mayordomo, J., Isarde-Alcántara, I., and Bischoff, J., 2011, Could large palaeoearthquakes break giant stalactites in Cacahuamilpa Cave? (Taxco, Central México): Corinth, Greece, $2^{\text {nd }}$ INQUAIGCP-567 International Workshop on Active Tectonics, Earthquake Geology, Archaeology and Engineering, p. 46-49.

Genty, D., Baker, A., and Vokal, B., 2001, Intra-and inter-annual growth rate of modern stalagmites: Chemical Geology, v. 176, p. 191-212. doi:10.1016/S0009-2541(00)00399-5.

Gilli, E., 1999, Breaking of speleothems by creeping of a karstic filling. The example of the Ribiere Cave (Bouches-du-Rhone): Comptes Rendus de l'Academie des Sciences, Series IIA: Earth and Planetary
Science, v. 329, no. 11, p. 807-813. doi:10.1016/S1251-8050(00)88636$\mathrm{X}$.

Gilli, É., 2005, Review on the use of natural cave speleothems as palaeseismic or neotectonics indicators: Comptes Rendus Geoscience, v. 337, p. 1208-1215. doi:10.1016/j.crte.2005.05.008.

Jaffey, A.H., Flynn, K.F., Glendenin, L.E., Bentley, W.C., and Essling, A.M., 1971, Precision measurement of half-lives and specific of ${ }^{235} \mathrm{U}$ and ${ }^{238} \mathrm{U}$ : Physical Review C, v. 4, p. 1889-1906. doi:10.1103/ PhysRevC.4.1889.

Meyer, M.C., Spötl, C., and Mangini, A., 2008, The demise of the Last Interglacial recorded in isotopically dated speleothems from the Alps: Quaternary Science Reviews, v. 27, p. 476-496. doi:10.1016/j. quascirev.2007.11.005.

Ozansoy, C., and Mengi, H., 2006, Mağarabilimi ve Mağaracılık: Ankara, Turkey, TÜBITAK populer bilim kitapları, 235, 337 p.

Papadopoulos, G.A., Daskalaki, E., Fokaefs, A., and Giraleas, N., 2007, Tsunami hazards in the eastern Mediterranean Sea: Strong earthquakes and tsunamis in the East Hellenic Arc and Trench system: Natural Hazards and Earth System Sciences, v. 7, p. 57-64. doi:10.5194/nhess-7-57-2007.

Pararas-Carayannis, G., 2011, The earthquake and tsunami of July 21, $365 \mathrm{AD}$ in the Eastern Mediterranean Sea - Review of impact on the ancient world - Assessment of recurrence and future impact: Science of Tsunami Hazards, v. 30, p. 253-292.

Polyak, V.J., and Asmerom, Y., 2001, Late Holocene climate and cultural changes in the southwestern United States: Science, v. 294, p. 148 151. doi:10.1126/science.1062771.

Postpischl, D., Agostini, S., Forti, P., and Quinif, Y., 1991, Palaeoseismicity from karst sediments: The "Grotta del Cervo" cave case study (Central Italy): Tectonophysics, v. 193, p. 33-44. doi:10.1016/00401951(91)90186-V.

Sbeinati, M.R., Darawcheh, R., and Mouty, M., 2005, The historical earthquakes of Syria: An analysis of large and moderate earthquakes from 1365 B.C. to 1900 A.D.: Annals of Geophysics, v. 48, p. 347-435. doi:10.4401/ag-3206.

Šbela, S., 2008, Broken speleothems as indicators of tectonic movements: Acta Carsologica, v. 37, no. 1, p. 51-62.

Şenoğlu, G., 2006, Mağara çökellerinin iz element içeriğinden paleoiklim koşullarının belirlenmesi [MSc thesis]: Ankara, Hacettepe Üniversitesi Fen Bilimleri Enstitüsü, 118 p.

Soloviev, S.L., Solovieva, O.N., Go, C.N., Kim, K.S., and Shchemikov, N.A., 2000, Tsunamis in the Mediterranean Sea 2000 BC - 2000 AD: Dordrecht, Netherlands, Kluwer Academic Publishers, Advances in Natural and Technological Hazards Research 13, 237 p.

Spötl, C., and Mangini, A., 2007, Speleothems and paleoglaciers: Earth and Planetary Science Letters, v. 254, p. 323-331. doi:10.1016/j.epsl. 2006.11.041.

Tinti, S., Armigliato, A., Pagnoni, G., and Zaniboni, F., 2005, Scenarios of giant tsunamis of tectonic origin in the Mediterranean: ISET Journal of Earthquake Technology, v. 42, no. 4, p. 171-188.

Treble, P., Shelley, J.M.G., and Chappell, J., 2003, Comparison of high resolution sub-annual records of trace elements in a modern (19111992) speleothem with instrumental climate data from southwest Australia: Earth and Planetary Science Letters, v. 216, no. 1, p. 141-153. doi:10.1016/S0012-821X(03)00504-1.

Van Beynen, P.E., Schwarcz, H.P., and Ford, D.C., 2004, Holocene climatic variation recorded in a speleothem from McFail's Cave: Journal of Cave and Karst Studies, v. 66, p. 20-27.

Webster, J.W., Brook, G.A., Railsback, L.B., Cheng, H., Edwards, R.L., Alexander, C., and Reeder, P.P., 2007, Stalagmite evidence from Belize indicating significant droughts at the time of preclassic abandonment, the Maya hiatus, and the classic Maya collapse: Palaeogeogrphy, Palaeoclimatology, Palaeoecology, v. 250, p. 1-17.

White, W.B., 2007, Cave sediments and paleoclimate: Journal of Cave and Karst Studies, v. 69, p. 76-93 